\title{
Superimposed-ice formation in summer on Ross Sea pack-ice floes
}

\author{
Toshiyuki KAWAMURA, ${ }^{1}$ Martin O. JEFFRIES, ${ }^{2}$ Jean-Louis TISON, ${ }^{3}$ H. Roy KROUSE ${ }^{4}$ \\ ${ }^{1}$ Institute of Low Temperature Science, Hokkaido University, Sapporo 060-0819, Japan \\ E-mail: kawat@lowtem.hokudai.ac.jp \\ ${ }^{2}$ Geophysical Institute, University of Alaska Fairbanks, Fairbanks, AK 99775-7320, USA \\ ${ }^{3}$ Laboratoire de Glaciologie, Département des Sciences de la Terre et de l'Environnement, Faculté des Sciences, CP 160/03, \\ Université Libre de Bruxelles, B-1050 Brussels, Belgium \\ ${ }^{4}$ Department of Physics and Astronomy, University of Calgary, 2500 University Drive NW, Calgary, Alberta T2N 1N4, Canada
}

\begin{abstract}
Austral summer sea-ice processes were investigated in January 1999 during a cruise of the R.V. Nathaniel B. Palmer in the central and eastern Ross Sea, Antarctica. The crystal texture, ${ }^{18} \mathrm{O} /{ }^{16} \mathrm{O}$ ratios, density and salinity of ice cores and of ice blocks 'perched' on slush at the ice surface were studied. The perched ice blocks had a distinctive polygonal granular (PG) crystal texture and very negative isotope signature that were also characteristic of layers at the top of first-year floes and of layers 'buried' below the surface in multi-year floes. The PG ice is superimposed ice that results from melting in the snow cover and refreezing at the slush surface and directly on top of ice floes. If PG ice is buried after the ice surface floods and the resultant slush freezes, then snow ice forms above the PG ice. The contribution of superimposed ice to floe surface mass balance and some implications with respect to weather and climate are discussed.
\end{abstract}

\section{INTRODUCTION}

Because of its low thermal conductivity, snow is an effective insulator that plays a key role in sea-ice thermodynamics. In the case of ice formation, the role of snow is often perceived as negative in that it retards the conductive heat flow through the ice, which reduces bottom growth rates and controls the ice thickness. On the other hand, if snow accumulates to sufficient depth and mass that overcome the buoyancy of the ice, the effect can be positive due to flooding and subsequent snow-ice formation on top of floes. Snow-ice formation is widespread in the Antarctic pack ice (e.g. Lange and others, 1990; Eicken and others, 1994; Worby and others, 1998), and in some regions (e.g. the Ross Sea) it makes a greater contribution than either frazil ice or congelation ice to the thermodynamic thickening of the ice cover (e.g. Jeffries and others, 2001).

Thickening by accretion of congelation ice at the bottom and snow ice at the top of floes is primarily a cold-season occurrence. During the warm season, Antarctic floes remain snow-covered and it was once believed that the snow did not melt at all (Andreas and Ackley, 1982). However, there is now ample evidence that melting and refreezing in the snow is widespread (Haas and others, 2001; Morris and Jeffries, 2001) and contributes to warm-season ice formation at the top of the ice in both the pack-ice and landfast-ice zones (Jeffries and others, 1994, 1997; Kawamura and others, 1997; Eicken, 1998; Haas and others, 2001).

Melt/freeze cycles in the snow in the warm season affect electromagnetic properties and remote-sensing signatures (e.g. Haas, 2001). They also promote biological activity, including high algal standing stocks, at the ice surface (Fritsen and others, 2001; Haas and others, 2001). Superimposed-ice formation associated with melt/freeze at the top of floes and landfast ice affects their mass balance, strength and durability (Kawamura and others, 1997; Haas and others, 2001).

This paper adds to the evidence for melt/freeze cycles in snow and superimposed-ice formation at the top of floes in summer in the Antarctic pack ice. Specifically, we discuss the oxygen isotopic composition, density and salinity of ice blocks and layers with a distinctive polygonal granular crystal texture that were perched on slush, had accumulated directly on the ice surface, and were 'buried' below the ice surface in the Ross Sea.

\section{METHODS}

A total of 65 ice cores with a total length of $63.68 \mathrm{~m}$ were obtained in January 1999 from 29 ice floes in the central and eastern Ross Sea (Fig. 1). Three floes $(008,017,028)$ were multi-year ice that was distinguished from first-year floes by a higher freeboard, due to deeper snow and thicker ice, and a rougher, more deformed surface. The depth of standing water/slush on the ice at the bottom of the snow was measured at $1 \mathrm{~m}$ intervals along $150 \mathrm{~m}$ transects prior to

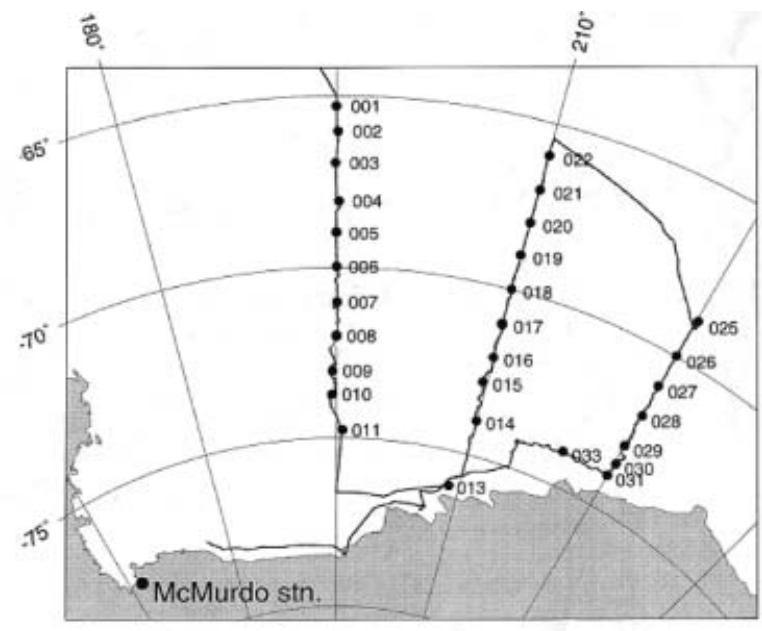

Fig. 1. Map of the study area and track of R.V. Nathaniel B. Palmer in the central and eastern Ross Sea in early 1999. Floes that were investigated are identified by Julian days 001 (1 January) to 033 (2 February). 
Table 1. Mean ( \pm 1 s.d.) salinity and $\delta^{18} \mathrm{O}$ values of snow, ice lenses and pipes, and slush. Values in parentheses are the number of samples analyzed

\begin{tabular}{lcc}
\hline & Salinity & $\delta^{18} \mathrm{O}$ \\
& $\%$ \%o & \\
\hline Snow & - & $-15.9 \pm 4.1(239)$ \\
Small ice lenses and pipes & $0.2 \pm 0.2(7)$ & $-15.7 \pm 2.9(7)$ \\
Large ice lenses & $0.4 \pm 0.2(16)$ & $-16.2 \pm 1.2(16)$ \\
Slush & $19.5 \pm 2.9(25)$ & $-6.4 \pm 2.6(25)$ \\
& & \\
\hline
\end{tabular}

drilling and measuring ice thicknesses on 20 floes. At each floe, the snow cover and slush were sampled, as described in Morris and Jeffries (2001), and a surface sea-water sample was taken using standard oceanographic techniques. In the science freezer aboard the ship, the cores were split and vertical thick sections made along the entire length of each core. The sections were illuminated between crossed polarizers, and the stratigraphy and crystal texture of the ice were documented. One-half of the split core was sampled according to stratigraphic and textural variability. Those samples were melted and, together with snow, slush and sea-water samples, sent to the University of Calgary for analysis of ${ }^{18} \mathrm{O} /{ }^{16} \mathrm{O}$ ratios using standard mass-spectrometer techniques. Four half-cores and three ice blocks that had been removed from the snow cover were shipped frozen to Hokkaido University. There, the stratigraphy and texture were documented. The ice density was then calculated from the measured volume and weight of rectangular ice pieces. The pieces were melted for salinity and oxygen isotope analysis (in Calgary), and thin sections were made and photographed in plain and polarized light.

\section{RESULTS}

The snow cover was isothermal and close to the melting point, and there were frequent small ice lenses and pipes (Fritsen and others, 2001; Morris and Jeffries, 2001). Snow samples with a salinity $<1 \%$ had very low $\delta^{18} \mathrm{O}$ values (Table 1). The ice lenses and pipes had very low salinity values and $\delta^{18} \mathrm{O}$ values almost identical to those of the snow (Table 1).

The snow cover remained intact throughout the cruise, and no melt ponds were observed on the surface of floes. However, there was widespread flooding at the base of the snow on all floes. Prior to drilling, $56 \%$ of the ice surface along the $150 \mathrm{~m}$ ice-thickness transects was flooded to a mean depth of $0.121 \mathrm{~m}(n=1529)$. The slush had salinity and $\delta^{18} \mathrm{O}$ values intermediate between those of snow and sea water (Tables 1 and 2).

Throughout the study area a layer of consolidated ice could be found at the bottom of the snow cover 'perched' directly on top of the slush layer and not in direct contact with the underlying ice surface. These $0.03-0.15 \mathrm{~m}$ thick layers were not continuous, and a thorough search was often required to find them. Particularly thick $(0.15 \mathrm{~m})$ perched ice layers were common during the early days of the cruise (floes 001-005; Fig. 1). They were characterized by a blocky appearance and rough bottom surface. Three ice blocks, up to $0.2 \mathrm{~m}$ wide and $0.15 \mathrm{~m}$ thick, were taken for further examination. They were hard and glassy, with a mean density of $862 \mathrm{~kg} \mathrm{~m}^{-3}(n=12)$ and had numerous air inclusions (Fig. 2a). The crystal texture was characterized by polygonal granular (PG) crystals with typical dimensions of $5-10 \mathrm{~mm}$ (Fig. 2b). The very low salinity and $\delta^{18} \mathrm{O}$ values were similar to those of the snow and ice lenses/pipes in the snow cover (Table 1).

PG ice layers with characteristics very similar to the perched ice blocks in the snow cover were found at the top of six cores from first-year floes 001, 002, 004 and 005 at latitudes $65-69^{\circ} \mathrm{S}$ along $165^{\circ} \mathrm{W}$ longitude (Fig. 1). The thickness of the first-year PG ice layers ranged from 0.105 to $0.2 \mathrm{~m}$. They contained numerous small inclusions, but the ice was much clearer than that below (Fig. 3). The polygonal grains were much larger than those in orbicular granular snow ice (Fig. 3a) and frazil ice, and, not surprisingly, quite different in appearance to columnar ice and platelet ice. The PG layers had very low salinity (mean $=0.05 \pm 0.01 \%$, $n=2$, core 005-01) and $\delta^{18} \mathrm{O}$ values compared to the ice below (e.g. Fig. 4a). $\delta^{18} \mathrm{O}$ values were very close to those of snow and much lower than those of slush and sea water (Tables 1 and 2). The density of first-year PG ice was measured only on two samples from core 005-01 (mean = $897 \pm 3 \mathrm{~kg} \mathrm{~m}^{-3}$ ).

PG ice layers were also found in three cores from multiyear floes (cores 008-02, 008-03 and 017-01; Fig. 1). Unlike the first-year PG layers, those in the multi-year ice were 'buried' below the surface. The thickness of the multi-year PG ice layers ranged from 0.11 to $0.29 \mathrm{~m}$ and the mean density was $816 \pm 44 \mathrm{~kg} \mathrm{~m}^{-3}$. Like the first-year PG ice, the multi-year PG ice contained far fewer inclusions (Fig. 5a) than, and was texturally quite different from, the ice above and below (Fig. 5b). The PG layer in core 017-01 was notable for an upper zone of very coarse crystals (the largest of all the PG crystals we observed) and a lower zone of finer-

Table 2. Mean $\left( \pm 1\right.$ s.d.) $\delta^{18} \mathrm{O}$ values of sea water, slush, snow and ice types in ice cores. Values in parentheses are the number of samples analyzed. FY, first-year ice; MY, multi-year ice

\section{FY cores with PG ice (6)}

$\%$
MY cores with PG ice (3)

$\%$
All cores (65)

$\%$

$\begin{array}{lc}\text { Polygonal granular ice (PG) } & -17.5 \pm 2.6(17) \\ \text { Snow ice } & -2.8 \pm 2.6(27) \\ \text { Frazil, congelation, platelet ice } & +0.8 \pm 0.8(33) \\ \text { Sea water } & -0.9 \pm 0.0(4) \\ \text { Slush } & -9.5 \pm 2.9(4) \\ \text { Snow (salinity }<1 \% \text { ) } & -16.8 \pm 4.3(35)\end{array}$

Polygonal granular ice (PG

Sea water

Snow (salinity $<1 \%$ )

$$
\begin{aligned}
& -7.3 \pm 3.2(11) \\
& -2.4 \pm 1.9(18) \\
& +1.0 \pm 0.3(18) \\
& -0.6(1) \\
& -7.4 \pm 2.1(2) \\
& -14.8 \pm 2.5(27)
\end{aligned}
$$

$-13.3+5.8(28)$

$-2.3 \pm 2.3(163)$

$+0.8 \pm 0.6(392)$

$-0.8 \pm 0.2(30)$

$-6.4 \pm 2.6(25)$

$-15.9 \pm 4.1(239)$ 

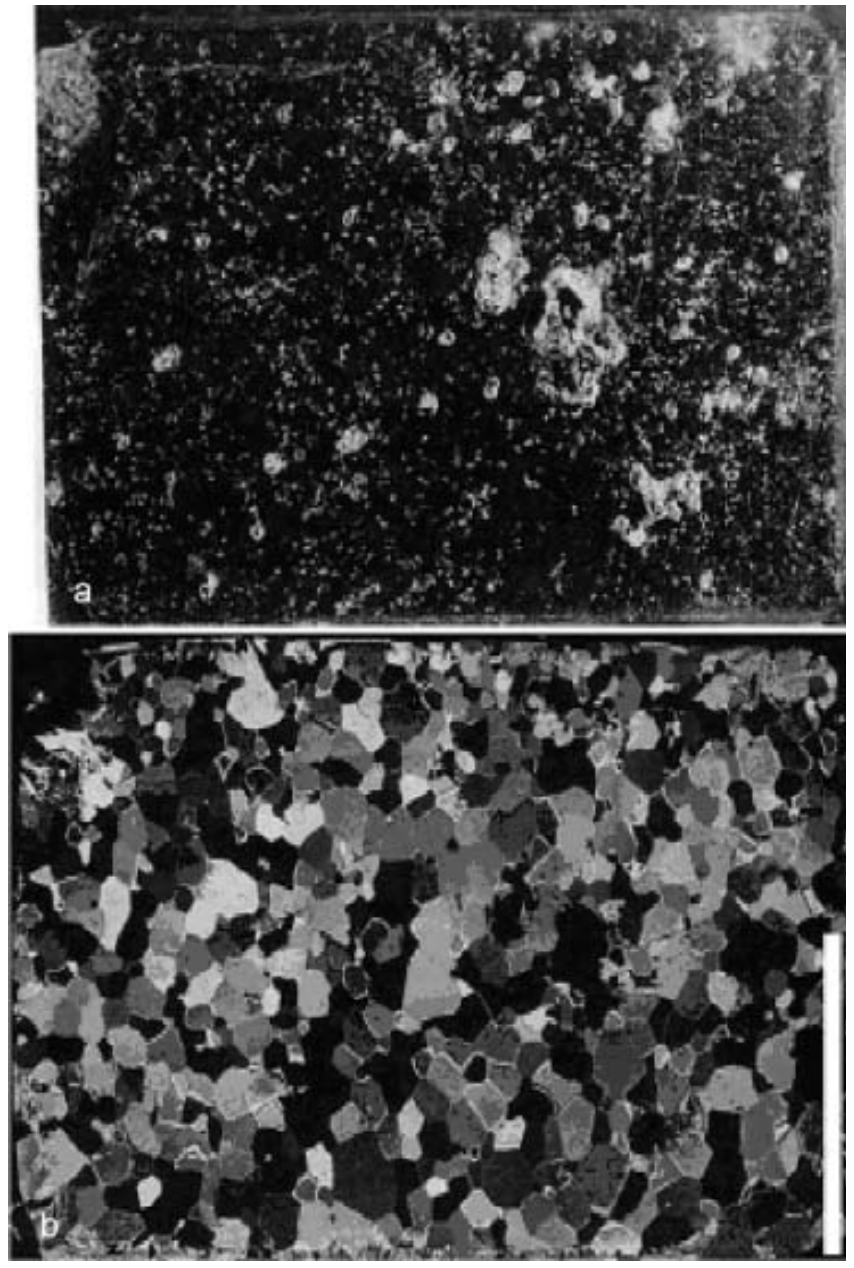

Fig. 2. Thin section (a) in plain light and (b) between crossed polarizers of an ice block that was 'perched' on the slush at the bottom of the snow cover. The horizontal white bar at the right of (b) represents $30 \mathrm{~mm}$.

grained crystals (Fig. 5b). Note also the vertically oriented tubular feature that appears to penetrate the PG layer from above (Fig. 5a). A similar feature occurred in the PG layer in core 008-02.

The $\delta^{18} \mathrm{O}$ values of multi-year PG ice were not as low as those in the first-year cores (Table 2), but were still significantly different from the other ice types (Table 2). The salinity and $\delta{ }^{18} \mathrm{O}$ profiles for a core with 'buried' PG ice emphasize these differences (Fig. 4b). The mean salinity of the PG layers in the multi-year cores was $2.1 \pm 1.3 \%$ $(n=15)$.

\section{DISCUSSION}

The PG ice is unmistakably superimposed ice. The crystal texture alone is sufficient to support this interpretation, based on the strong similarity between the texture illustrated here and what others have observed on Antarctic sea ice previously (Jeffries and others, 1994; Kawamura and others, 1997; Eicken, 1998; Haas and others, 2001). The negligible salinity of the first-year PG ice, the similarity between firstyear PG ice and snow $\delta^{18} \mathrm{O}$ values, and the contrast between those and the $\delta^{18} \mathrm{O}$ values of the underlying sea ice are additional strong evidence for its origin.

Koerner (1970) defines superimposed ice as 'ice which is

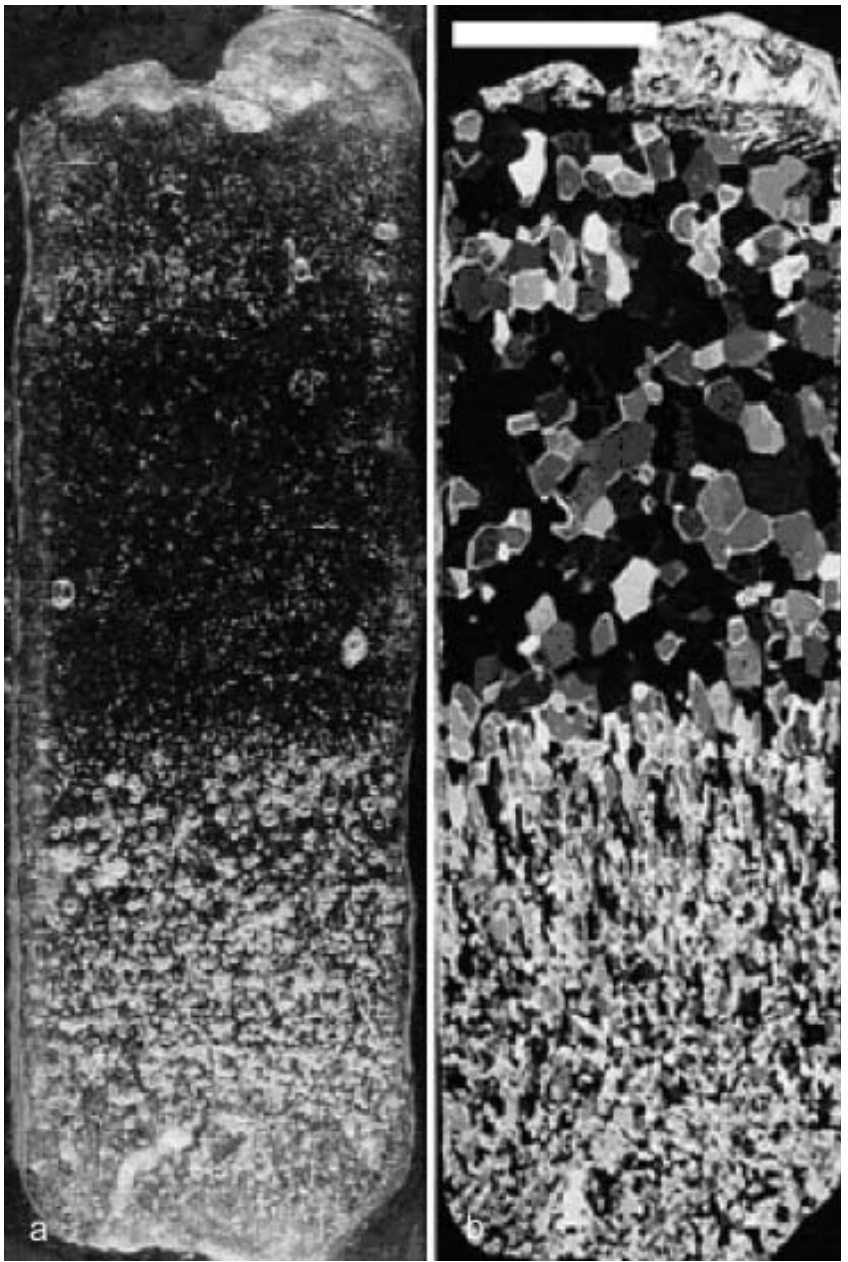

Fig. 3. Polygonal granular ice at the top of core 005-01 (a) in plain light and (b) between crossed polarizers. The horizontal white bar at the top of (b) represents $30 \mathrm{~mm}$.

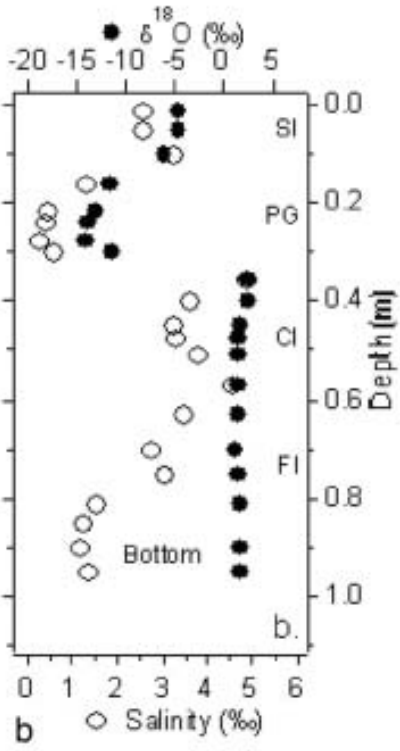

Fig. 4. Salinity and $\delta^{18} \mathrm{O}$ profiles in (a) first year ice core 005-01 and (b) multi-year ice core 017-01. The stratigraphy and ice types in each core are identified on the right side of each graph with abbreviations PG (polygonal granular ice), SI (snow ice), FI (frazil ice) and $\mathrm{Cl}$ (congelation ice). 

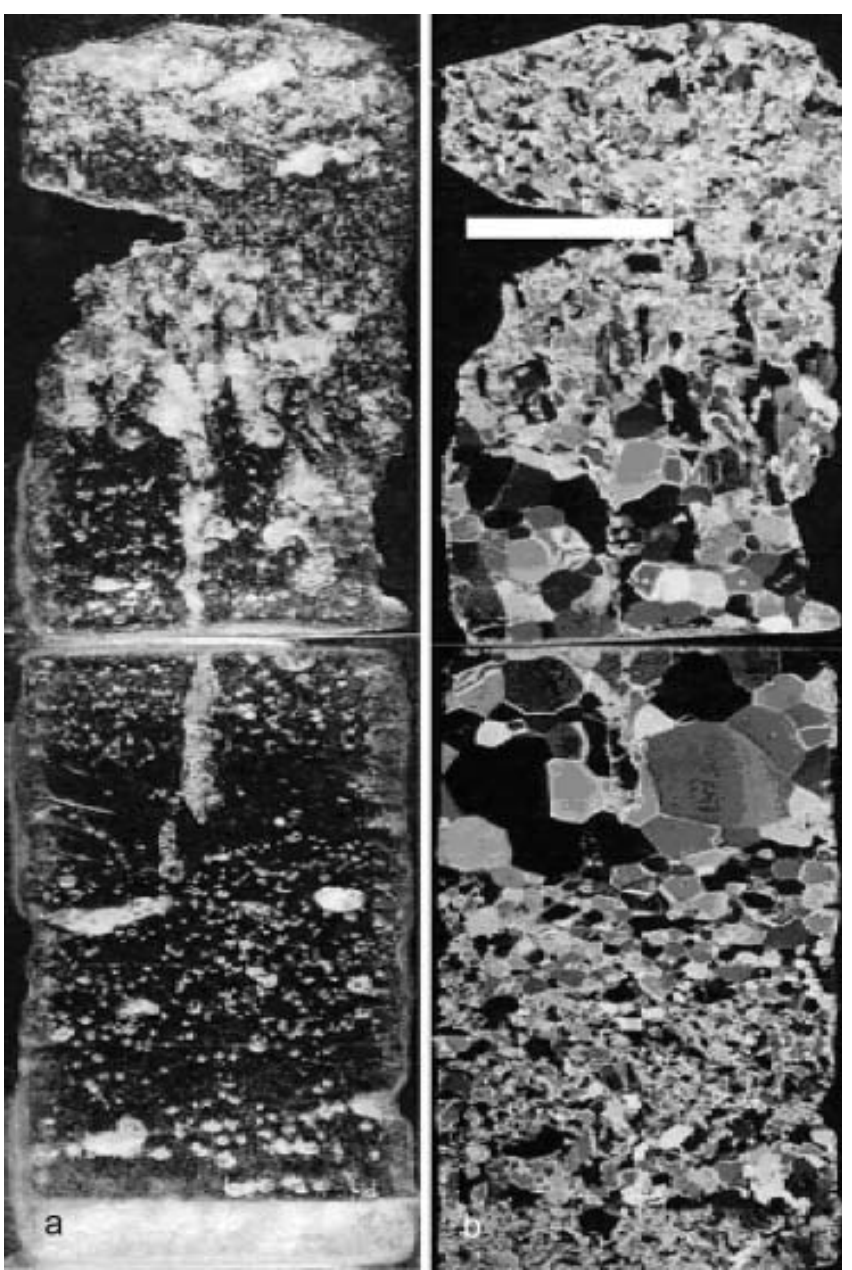

Fig. 5. Polygonal granular ice at the top of multi-year ice core 017-01 (a) in plain light and (b) between crossed polarizers. The horizontal white bar near the top of (b) represents $30 \mathrm{~mm}$.

formed by the refreezing of melt water from the snow pack onto the glacier surface... Superimposed ice does not include ice formed from refreezing of melt water within the firn or snow pack.' Here we are looking at sea ice rather than a glacier, but the PG ice at the top of the first-year cores nevertheless meets Koerner's criteria. That is, the meltwater refroze directly onto the floe surface (Fig. 6a). On the other hand, the consolidated ice layers and blocks 'perched' on slush do not meet the criteria. We must ask where they originated, and why the PG layers in the multi-year cores were 'buried' and have higher salinity and $\delta^{18} \mathrm{O}$ values than the first-year PG ice.

The slush layer in the Ross Sea was primarily due to percolation of sea water upward through the warm (almost $0^{\circ} \mathrm{C}$ ), permeable ice that was often depressed below sea level due to the mass of snow (Fig. 6bi) (Jeffries, unpublished data). The presence of the consolidated ice layers and blocks, and the size and shape of the blocks, perched on the slush was unexpected. Haas and others (2001) have since reported similar ice layers, but not blocks, in the Weddell Sea and described the process classification of the summer surface process. It is suggested that the ice layers form initially when less dense, fresh meltwater percolating through the snow refreezes at the surface of the cold, denser slush (Fig. 6bii), and they thicken further by the refreezing of meltwater being added from above (Haas and others, 2001).
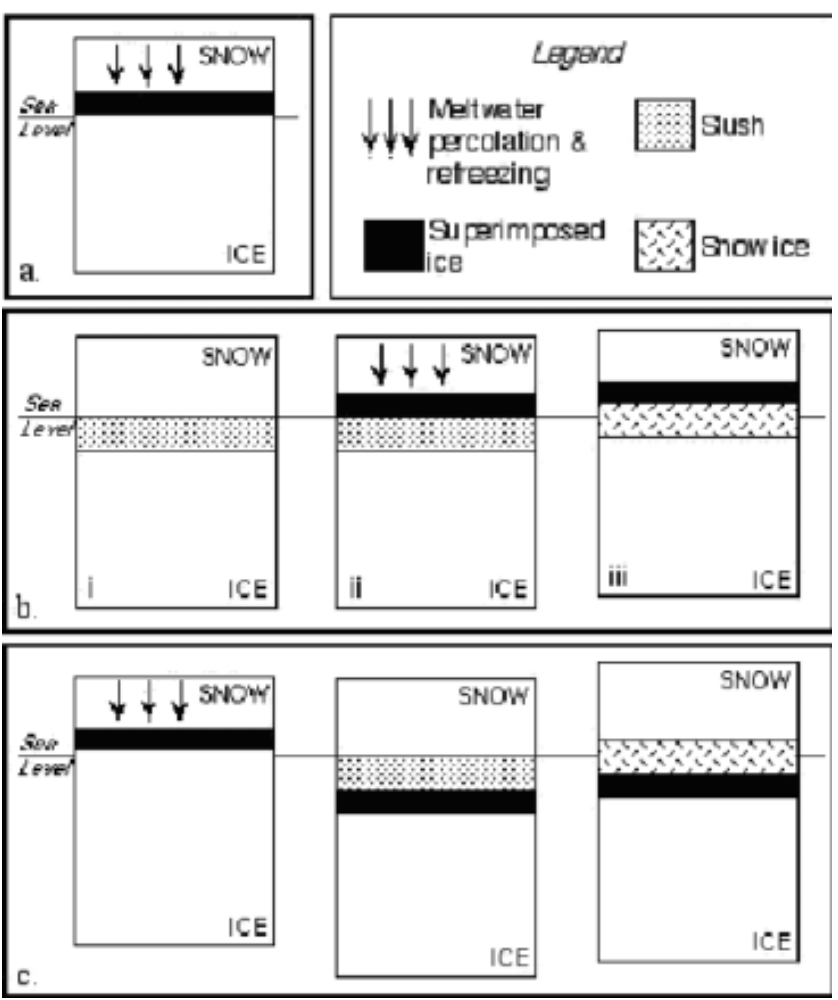

Fig. 6. Conceptual models of superimposed-ice formation in cores described in this paper: (a) on an ice surface that does not subsequently flood; (b) as a block 'perched' on top of slush that freezes in the subsequent autumn; and (c) on an ice surface that subsequently floods, the slush freezes, and the superimposed ice becomes 'buried' below the new ice surface.

The discontinuous occurrence of the perched ice blocks and other ice layers in the snow cover might seem unusual, but can be attributed to the probability that meltwater percolation and refreezing are not continuous in time and space. Patchy melting and refreezing events, and variable rates, probably account for the thickness/roughness variations and horizontally discontinuous occurrence of the perched ice layers and blocks. Also, rather than refreeze at the surface of the slush, meltwater might mix with the slush, and perched ice layers/blocks will not form. We have chosen to call them perched layers and blocks, but they are, in fact, simply superimposed on the slush layer. The slush that lies between a perched ice layer/block and the underlying floe surface is a 'gap' that provides a habitat for productive surface and freeboard communities of micro-organisms (Fritsen and others, 2001; Haas and others, 2001).

If a perched ice layer/block survives the summer, we propose that it can become an integral part of the floe in the autumn as air and snow temperatures decrease, and the slush layer freezes to form snow ice in the gap between the bottom of the ice layer/block and the top of the original floe surface (Fig. 6biii). Whether the PG ice layer at the top of a floe forms in this way, or in the more traditional mode of superimposed-ice formation directly on the ice surface (Fig. 6a), the PG ice will be 'buried' below snow ice at the surface of the floe if there is subsequent flooding and slush formation, followed by freezing (Fig. 6ciii). Hence the occurrence of 'buried' PG ice in the multi-year cores. Similar 'buried' PG layers have been reported in this region by Jeffries and others (1994, figs 4 and 10c). The dual 
layering with contrasting crystal sizes in the 'buried' PG ice in core 017-01 (Fig. 5b) probably represents two episodes of melting and refreezing, and differences in freezing rates during each episode. The water that formed the lower, finergrained layer probably froze more quickly than the water that formed the upper, coarser layer.

All ice cores were obtained under similar conditions and it seems unlikely that the relatively high salinity and $\delta^{18} \mathrm{O}$ values of multi-year PG ice compared to first-year PG ice would be due to contamination while coring in a salty sampling environment. We do not discount the possibility that such contamination occurred, but the salinity and $\delta^{18} \mathrm{O}$ values of multi-year PG ice might be primarily the result of a natural process. Haas and others (2001) have described saltwater droplets melting their way into PG ice from the submerged, flooded ice surface. We propose that this process leads to the formation of the vertically oriented tubular features observed in the PG layers of cores 017-01 (Fig. 5a) and 008-02. They are, in effect, brine drainage tubes that are transferring brine into the PG layers from above. The mixing of this brine and the PG ice in a melted sample could account for the relatively high observed salinity and $\delta^{18} \mathrm{O}$ values.

The thickness of the PG ice layers indicates that there can be considerable melting in the snow and summer ice accumulation at the top of first-year floes. Assuming an initial PG ice density of $897 \mathrm{~kg} \mathrm{~m}^{-3}$ (as observed in first-year core 005-01), the $0.11-0.29 \mathrm{~m}$ thick superimposed-ice layers represent a water equivalent transfer of 0.098$0.26 \mathrm{~m}$ of snow to the ice surface. Or, assuming an initial dry, cold snow density of $320 \mathrm{~kg} \mathrm{~m}^{-3}$ (Morris and Jeffries, 2001), the superimposed-ice layers correspond to a snow thickness of $0.34-0.90 \mathrm{~m}$. Just as flooding and snow-ice formation significantly deplete the snow cover and add to the ice cover in the cold season (Jeffries and others, 2001), so too do snowmelting and superimposed-ice formation in the warm season. Overall, there is no loss of mass at the floe surface (Haas and others, 2001).

Although the PG ice layers were quite thick and comprised $8-30 \%$ of the length of the cores in which they were found, superimposed ice made only a small contribution to pack-ice development as a whole, as indicated by its proportion of the total length of ice core examined (Table 3). Much of the superimposed ice occurred in first-year cores at the beginning of the cruise, and perhaps it was only in this region that the conditions necessary for superimposed-ice formation were met while we were in the pack ice in January 1999. The conditions necessary for superimposedice formation obviously had been met in previous summers elsewhere in the pack ice, as evidenced by the multi-year PG ice.

Rather than be concerned with the small proportion of superimposed ice in the cores, we conclude this section by proposing that it is more important to focus on the fact that superimposed ice was forming at all. On a glacier, the lower boundary of the superimposed-ice zone is the equilibrium line, and below that is the ablation zone where there is a net loss of ice over the course of a year (Paterson, 1994, p. 11). By analogy, the occurrence of superimposed ice on sea-ice floes indicates a snow cover at an advanced stage of melting not far removed from complete disappearance. This would lead to melt-pond formation and, presumably, accelerated sea-ice decay, as occurs in the Arctic. The observation of superimposed ice in the Ross Sea and elsewhere (Jeffries and
Table 3. Proportion of ice types in cores as a function of the total length of core examined

\begin{tabular}{lccc}
\hline & First-year ice & Multi-year ice & All ice \\
& $\%$ & $\%$ & $\%$ \\
\hline Superimposed ice & 1.7 & 5.5 & 2.4 \\
Snow ice & 22.1 & 10.0 & 19.8 \\
Frazil ice & 46.8 & 47.9 & 47.0 \\
Congelation ice & 29.1 & 32.5 & 29.8 \\
Other (platelet ice, cavities) & 0.3 & 4.1 & 1.0 \\
& & & \\
\hline
\end{tabular}

others, 1994, 1997; Kawamura and others, 1997; Eicken, 1998; Haas and others, 2001) suggests that the summer snow and ice cover exist in a more delicate balance with the weather and climate than has previously been recognized. What remains to be determined is what conditions are required to tip the balance towards complete snowmelt and the formation of melt ponds, which have been observed occasionally on Antarctic floes (Haas and others, 1992; Low, 1995). This is a vital issue in view of the regional physical and biological importance, and global significance of Antarctic sea ice.

\section{CONCLUSION}

The crystal texture, ${ }^{18} \mathrm{O} /{ }^{16} \mathrm{O}$ ratios, density and salinity of ice cores and of ice blocks 'perched' on slush at the surface of ice floes in summer in the central and eastern Ross Sea have been described. The distinctive polygonal granular (PG) texture and isotopic signature of the perched blocks, ice layers at the top of first-year floes, and ice layers 'buried' below the surface of multi-year floes are characteristic of superimposed ice. It is the result of melting in the snow cover and freezing of the water at the slush surface or directly on top of floes. Flooding after superimposed-ice accretion and subsequent snow-ice formation buries PG ice below the surface. Superimposed ice represents a diminution of the snow cover by mass transfer to the ice, but no net loss of mass at the surface of floes. Superimposed ice also indicates that the snow had reached an advanced stage of melting only one step removed from total disappearance and the formation of melt ponds. Thus, while PG ice was a relatively small proportion of the total ice mass (as represented by the total length of ice cores examined), the fact that it occurred at all is significant in view of the implications with regard to sea ice and its sensitivity to weather and climate variability and change.

\section{ACKNOWLEDGEMENTS}

This work was supported by a Grant-in-Aid for Scientific Research (13490002) from the Japanese Ministry of Education, Culture, Sports, Science and Technology to T.K., and US National Science Foundation grant OPP 9614844 to M.O.J. J.-L.T. is a Research Associate at the Fonds National de la Recherche Scientifique (FNRS), Belgium, and acknowledges the support of the Belgian Antarctic Program (SSTC, Science Policy Office) for his participation in this project. H.R.K. thanks the Canadian Natural Science and Engineering Research Council for its support of the Stable Isotope 
Laboratory, University of Calgary. We thank M. Gowing, C. Venn, S. Nihashi and T. Tin for their assistance with ice coring and analysis. We are grateful to the captain and crew of the Nathaniel B. Palmer, and Antarctic Support Associates personnel for their support.

\section{REFERENCES}

Andreas, E. L. and S. F. Ackley. 1982. On the differences in ablation seasons of Arctic and Antarctic sea ice. J. Atmos. Sci., 39(2), 440-447.

Eicken, H. 1998. Deriving modes and rates of ice growth in the Weddell Sea from microstructural, salinity and stable-isotope data. In Jeffries, M. O., ed. Antarctic sea ice: physical processes, interactions and variability. Washington, DC, American Geophysical Union, 89-122. (Antarctic Research Series 74.)

Eicken, H., M. A. Lange, H.-W. Hubberten and P. Wadhams. 1994. Characteristics and distribution patterns of snow and meteoric ice in the Weddell Sea and their contribution to the mass balance of sea ice. Ann. Geophysicae, 12(1), 80-93.

Fritsen, C.H., S. L. Coale, D.R. Neenan, A.H. Gibson and D. L. Garrison. 2001. Biomass, production and microhabitat characteristics near the freeboard of ice floes in the Ross Sea, Antarctica, during the austral summer. Ann. Glaciol., 33, 280-286.

Haas, C. 2001. The seasonal cycle of ERS scatterometer signatures over perennial Antarctic sea ice and associated surface ice properties and processes. Ann. Glaciol., 33, 69-73.

Haas, C., T. Viehoff and H. Eicken. 1992. Sea-ice conditions during the Winter Weddell Gyre-Study 1992 ANT X/4 with RV Polarstern: shipboard observations and AVHRR satellite imagery. Alfred-Wegener-Inst. für Polar- und Meeresfors., Bremerhaven, Germany, Tech. Rep. 34.

Haas, C., D. N. Thomas and J. Bareiss. 2001. Surface properties and processes of perennial Antarctic sea ice in summer. J. Glaciol., 47(159), 613-625.

Jeffries, M. O., R. A. Shaw, K. Morris, A. L. Veazey and H. R. Krouse. 1994. Crystal structure, stable isotopes $\left(\delta^{18} \mathrm{O}\right)$, and development of sea ice in the Ross, Amundsen, and Bellingshausen seas, Antarctica. J. Geophys. Res., 99(C1), 985-995.

Jeffries, M.O., A.P. Worby, K. Morris and W. F. Weeks. 1997. Seasonal variations in the properties and structural composition of sea ice and snow cover in the Bellingshausen and Amundsen Seas, Antarctica. J. Glaciol., 43(143), 138-151.

Jeffries, M.O., H.R. Krouse, B. Hurst-Cushing and T. Maksym. 2001. Snow-ice accretion and snow-cover depletion on Antarctic first-year sea-ice floes. Ann. Glaciol., 33, 51-60.

Kawamura, T., K.I. Ohshima, T. Takizawa and S. Ushio. 1997. Physical, structural and isotopic characteristics and growth processes of fast sea ice in Lützow-Holm Bay, Antarctica. J. Geophys. Res., 102(C2), 3345-3355.

Koerner, R. M. 1970. Some observations on superimposition of ice on the Devon Island ice cap, N.W.T., Canada. Geogr. Ann., 52A(1), 57-67.

Lange, M. A., P. Schlosser, S. F. Ackley, P. Wadhams and G.S. Dieckmann. 1990. ${ }^{18} \mathrm{O}$ concentrations in sea ice of the Weddell Sea, Antarctica. J. Glaciol., 36(124), 315-323.

Low, D. 1995. The validation of ERS-1 summer SAR data for Antarctic sea ice. (M.Sc. thesis, University of Cambridge.)

Morris, K. and M.O. Jeffries. 2001. Seasonal contrasts in snowcover characteristics on Ross Sea ice floes. Ann. Glaciol., 33, 61-68.

Paterson, W.S.B. 1994. The physics of glaciers. Third edition. Oxford, etc., Elsevier.

Worby, A. P., R. A. Massom, I. Allison, V. I. Lytle and P. Heil. 1998. East Antarctic sea ice: a review of its structure, properties and drift. In Jeffries, M. O., ed. Antarctic sea ice: physical processes, interactions and variability. Washington, DC, American Geophysical Union, 41-67. (Antarctic Research Series 74.) 